\title{
Region-specific nitric oxide production in cytosolic and mitochondrial compartments of the rat brain tissues following chronic stress-induced depression-like behavior
}

\author{
N. S. Nazaryan, N. H. Movsesyan, N. Kh. Alchujyan, H. A. Movsesyan, \\ A. G. Guevorkian, H. L. Hairapetyan, K. A. Barsegyan, G. A. Kevorkian
}

H. Buniatian Institute of Biochemistry NAS, Republic of Armenia

5/1, P. Sevak Str., Yerevan, Republic of Armenia, 0014

h2moska@rambler.ru

\begin{abstract}
Aim. To study subcellular nitrergic response in the rat brain regions following chronic stress-induced depression-like behavior. Methods. An animal model of depression induced by chronic circadian stress (CCS) established in our laboratory was used. The L-arginine, L-citrulline and reactive nitrogen species (RNS) levels were determined spectrophotometrically. Results. Immediately after CCS and four days later, a depression-like behavior of rats was observed and accompanied by a substantial persistent elevation of the L-arginine, L-citrulline and RNS levels with a simultaneous up-regulation of the inducible nitric oxide synthase (iNOS) in both cytosolic and mitochondrial compartments of the rat prefrontal cortex, striatum, hippocampus, and hypothalamus, and a down-regulation of their cytosolic constitutive NOS isoforms (cNOS), mitochondrial cNOS was not significantly changed, with the exception for hypothalamus, in which the latter dropped. Conclusions. Compromised balance of the L-arginine levels and NO synthesis in both mitochondria and cytosol in the limbic brain appears to be implicated in the pathogenesis of depression and pathological anxiety.
\end{abstract}

Keywords: L-arginine, brain, chronic stress, depression-like behavior, mitochondria, nitric oxide synthase.

Introduction. Nitric oxide (NO) is a neuronal messenger and a potent modulator of mitochondrial respiration $[1,2]$. Mitochondrial dysfunction and L-arginine NO pathway are considered a likely cause of some psychiatric disorders including depression [3, 4]. Recent studies show the presence of a new calcium-activated constitutive form of the NO synthase (NOS) enzyme in mitochondria [5]. Chronic stress is known to be involved in the depression development.

Using the established in our laboratory animal model of depression induced by chronic circadian stress (CCS), we aimed to assess: (i) the levels of substrate and

(C) Institute of Molecular Biology and Genetics, NAS of Ukraine, 2011 products of NO synthesis (in vivo), (ii) the contribution of constitutive forms of NOS (cNOS), involved in neurotransmission and regulated vascular tone and tissue perfusion in nervous system, as well as inducible NOS (iNOS), the effector molecule of innate immune response, to the production of $\mathrm{NO}$ (in vitro) in cytosolic and mitochondrial compartments of the brain regions responsible for the anticipatory chronic stress responses.

Materials and methods. Six stressors (forced swimming, food deprivation, ether inhalation, restraint, cold and orthostatic stress) for 2 weeks were randomly applied to young male Wistar rats at the appropriate time points of circadian rhythm to induce a depression-like behavior [6]. 

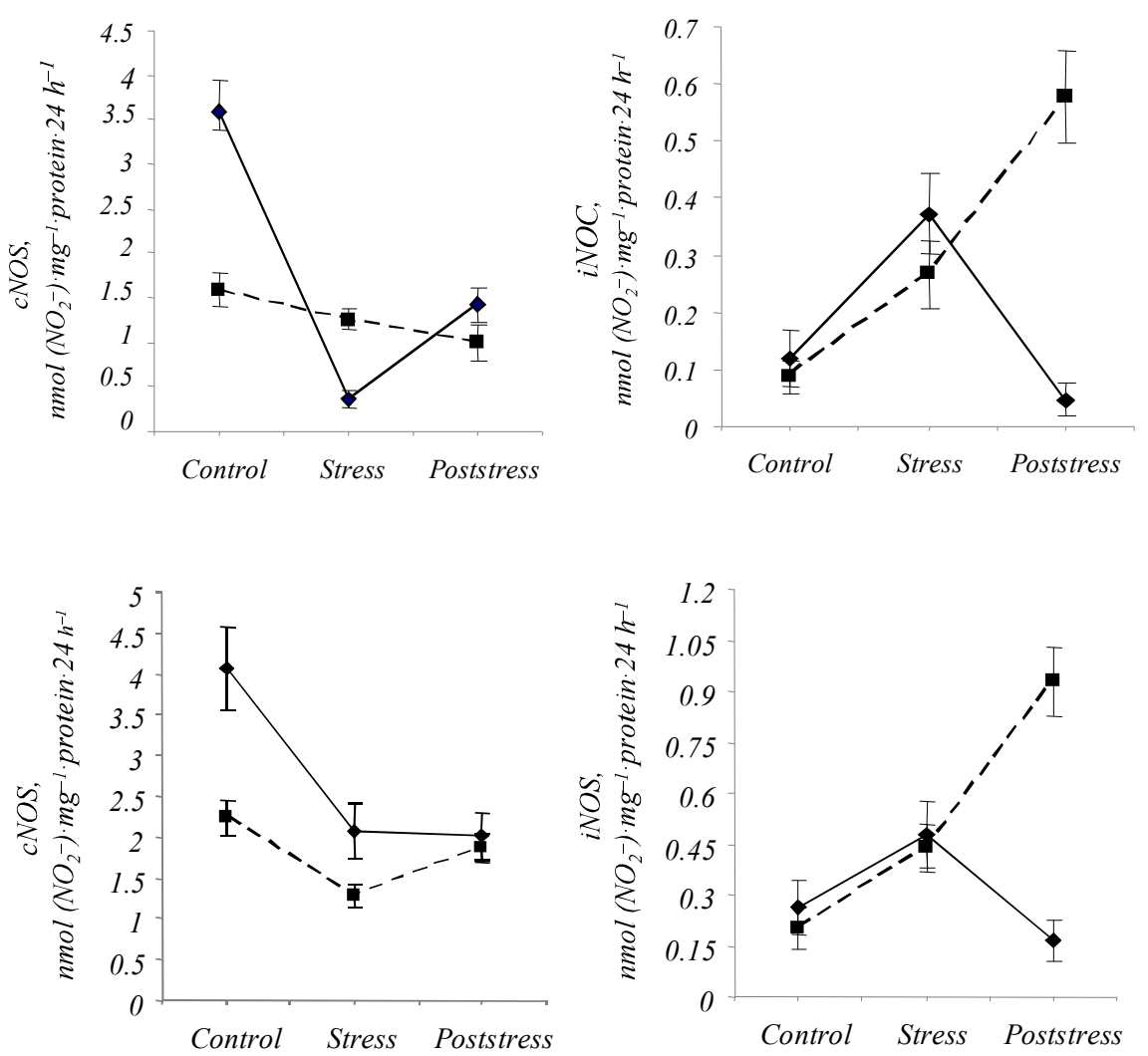

Fig. 1. Chronic stress-induced changes in the activity of both constitutive nitric oxide synthase isoforms (cNOS) and inducible nitric oxide synthase (iNOS) in cytosol and mitochondria from the prefrontal cortex of rats. Data are expressed as $M \pm \mathrm{SEM}$, statistical comparisons made by one way ANOVA followed by the Holm-Sidak test used for all pairwise comparisons: $F=49.1, \mathrm{p}<0.001 ; F=$ $=2.9, \mathrm{p}=0.063(\mathrm{cNOS}) ; F=11.7, \mathrm{p}<0.001$; $F=17.1, \mathrm{p}<0.001$ (iNOS) relating to cytosol and mitochondria, respectively. Differences are considered significant if $\mathrm{p}<0.05$

Fig. 2. Chronic stress-induced changes in the activity of both constitutive nitric oxide synthase isoforms (cNOS) and inducible nitric oxide synthase (iNOS) in cytosol and mitochondria from the striatum of rats. Data are expressed as $M \pm \operatorname{SEM}(n=18)$, statistical comparisons made by one way ANOVA followed by the Holm-Sidak test used for all pairwise comparisons: $F=15.4, \mathrm{p}<0.001 ; F=7.2, \mathrm{p}=$ $=0.002(\mathrm{cNOS}) ; F=3.8, \mathrm{p}=0.029 ; F=22.4$, $\mathrm{p}<0.001$ (iNOS) relating to cytosol and mitochondria, respectively. Differences are considered significant if $\mathrm{p}<0.05$
The total NOS activity was assessed by measuring with the Griess reaction [7] an accumulation of NO and its stable metabolites (reactive nitrogen species, RNS) during a long-term incubation of brain samples in the presence of calcium, L-arginine and NOS cofactors. The iNOS activity was determined in the presence of EDTA (omitting calcium from the incubation medium). The cNOS activity was calculated by subtracting the activity of iNOS from that of total NOS. The NOS activity was expressed as nmol nitrite $\left(\mathrm{NO}_{2}^{-}\right) \mathrm{mg}^{-1}$ protein $24 \mathrm{~h}^{-1}$. The concentrations of L-arginine and L-citrulline were determined spectrophotometrically [6].

Results and discussion. Immediately after CCS (group I) and four days later (group II) the depression-like behavior of rats was developed and accompanied with a subsequent elevation of the L-arginine, Lcitrulline and RNS amounts in both cytosol and mitochondria of the prefrontal cortex (PFC), striatum, hippocampus, and hypothalamus compared to control. Larginine levels increased in both cytosolic and mitochondrial compartments of the PFC, striatum, hippo- campus, and hypothalamus, in group I of 8.8- and 5.9, 2.2- and 2.4, 2.9- and 15.1, 9.9- and 11.7-fold, and in group II of 2.6- and 8.8, 6.1- and 6.4, 9.3- and 5.0, 9.9and 11.1-fold, compared respectively to control. Simultaneously, a persistent upregulation of iNOS accompanied by an elevation of the reactive nitro gen species levels was observed in the mitochondria of all the regions studied. Cytosolic iNOS activity also markedly increased in the hippocampus and hypothalamus, while that of PFC and striatum after short-term activation (group I) dropped lower than control values (group II). Contrary to iNOS, cytosolic cNOS activity decreased by $9.9,4.7$, 3.7 and 2-fold (group I) and 2.5, 1.8, 2.6 and 2-fold (group II) in the PFC, hypothalamus, hippocampus, and striatum, compared respectively to control. The mitochondrial cNOS activity was not significantly changed in the PFC, striatum and hippocampus, but diminished by 2.9 (group I) and 2-fold (group II) in the hypothalamus. Contrary to cNOS, a persistent activation of iNOS was observed in mitochondria of all the regions studied, with a remarkable domination of mitochondrial iNOS over cytosolic one, with exception for hypothalamus. 

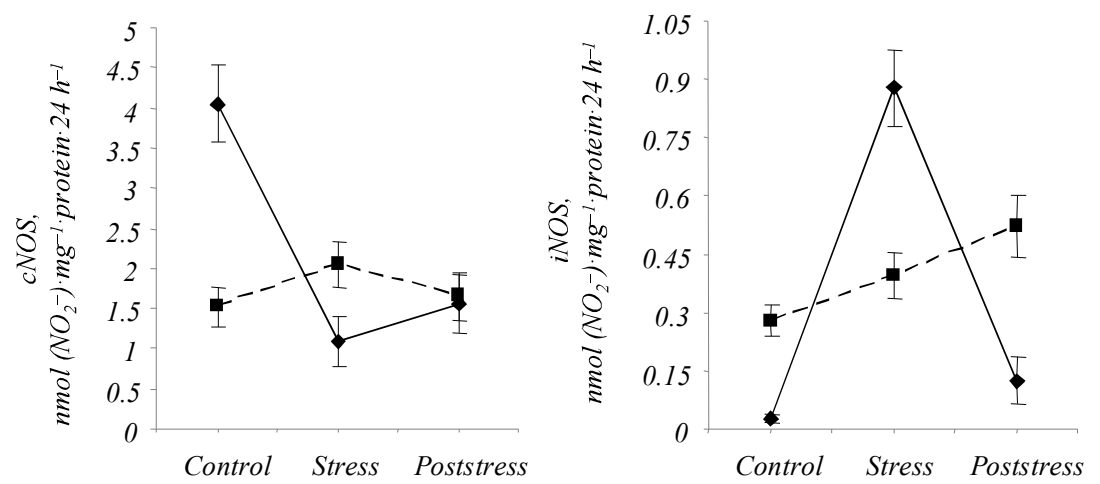

Fig. 3. Chronic stress-induced changes in the activity of both constitutive nitric oxide synthase isoforms (cNOS) and inducible nitric oxide synthase (iNOS) in cytosol and mitochondria from the hippocampus of rats. Data are expressed as $M \pm \mathrm{SEM}$ $(n=18)$, statistical comparisons made by one way ANOVA followed by the Holm-Sidak test used for all pairwise comparisons: $F=43.8, \mathrm{p}<0.001 ; F=$ $=3.1, \mathrm{p}=0.054(\mathrm{cNOS}) ; F=47.4, \mathrm{p}<0.001 ; F=$ $=3.8, \mathrm{p}=0.029$ (iNOS) relating to cytosol and mitochondria, respectively. Differences are considered significant if $\mathrm{p}<0.05$
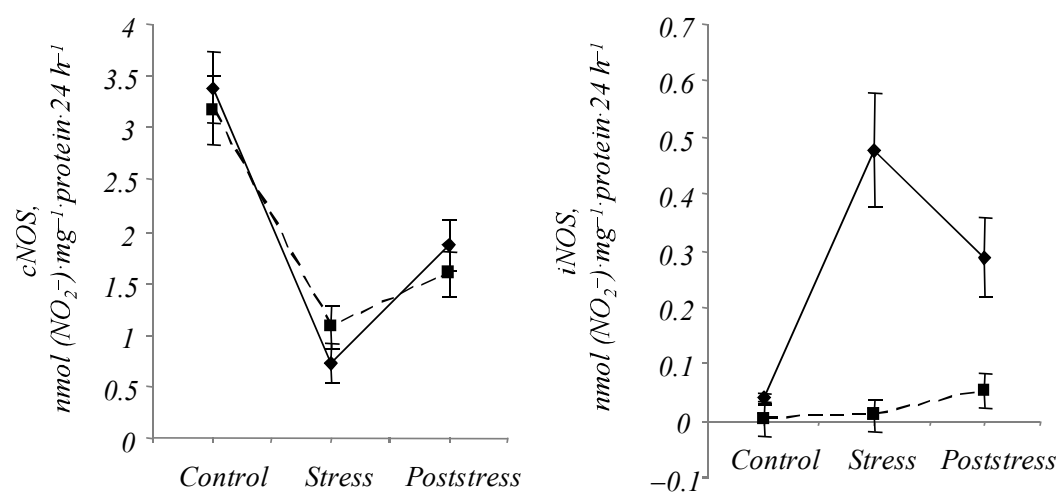

Fig. 4. Chronic stress-induced changes in the activity of both constitutive nitric oxide synthase isoforms (cNOS) and inducible nitric oxide synthase (iNOS) in cytosol and mitochondria from the hypothalamus of rats. Data are expressed as $M \pm \mathrm{SEM}$, statistical comparisons made by one way ANOVA followed by the Holm-Sidak test used for all pairwise comparisons: $F=35.7, \mathrm{p}<0.001 ; F=26.7$, $\mathrm{p}<0.001(\mathrm{cNOS}) ; F=6.4, \mathrm{p}=0.003 ; F=16.7, \mathrm{p}<$ $<0.001$ (iNOS) relating to cytosol and mitochondria, respectively. Differences are considered significant if $\mathrm{p}<0.05$

The cytosolic iNOS activity also significantly increased in the hippocampus, and hypothalamus, whereas it dropped (group II) by 2.5 and 1.6-fold in the PFC and striatum after short-term activation (group I) compared respectively to the control.

Thus, CCS-induced substantial lasting elevation of the L-arginine levels in the cellular compartments may facilitate the activation of iNOS, a high-output form strongly dependent on the presence of L-arginine, which availability may even become a rate-limiting step in the iNOS activity [8]. Up-regulation of iNOS might contribute to the elevation of L-citrulline, and RNS intracellular levels observed, and overall inhibition of the cNOS, because iNOS-derived high NO concentrations may inhibit the cNOS through formation of the stable inhibitory nitrosyl species [5]. The iNOS can produce $\mathrm{NO}$ for prolonged periods and a deleterious effect of excessive $\mathrm{NO}$ in the tissues is mediated by a potent oxidant, peroxynitrite $\left(\mathrm{ONOO}^{-}\right)$, that is readily formed from superoxide and $\mathrm{NO}$ produced together during the stress [5, 9]. NO-induced persistent mitochondrial damage [10] appears to be associated with the upregula- tion of iNOS in the mitochondria of the brain major regions, and cytosolic iNOS in the hippocampus, and hypothalamus, as well.

Our data are supported by the findings that the chronic stress-induced depression-like behavior is accompanied by the activation of iNOS in the brain and its inhibition prevents depression [11]. At the same time down-regulation of the cNOS could affect central release of neurotransmitters and messengers, as well as cerebral hemodynamics $[5,12]$.

Conclusions. Our results highlight the importance of differring the pathological effects driven by the distinct NOS forms when assessing their roles in mood disorders. The compromised balance of the L-arginine levels and NO synthesis in both mitochondria and cytosol appears to be implicated in the brain region-specific biochemical changes leading to mitochondrial dysfunction, energy impairment and neurotransmission disturbances attributed to counter-parted changes in the activity of distinct NOSs involved in the pathogenesis of depression/ anxiety. Given that dysfunctions in the limbic brain have been implicated to mood disorders and neurodegenera- 
tive diseases, it would be meaningful the searching for the agents against the metabolic disturbances found.

Н. С. Назарян, Н. О. Мовсесян, Н. Х. Алчуджян, О. А. Мовсесян, А. Г. Геворкян, Р. Л. Айрапетян, К. А. Барсегян, Г. А. Геворкян

Різне продукування оксиду азоту в цитозольному i мітохондріальному компартментах тканин головного мозку щурів при депресивноподібній поведінці, індукованій хронічним стресом

Резюме

Мета. Вивчення субклітинної нітрергічної відповіді у ділянках мозку щурів при депресивноподібній поведінці, індукованій хронічним стресом. Методи. Використано розроблену в нашій лабораторї тваринну (щур) модель депресії, індуковану хронічним циикадіанним стресом (ХЦC). L-аргінін, L-циитрулін $і$ активні форми азоту (АФА) визначали спектрофотометрично. Результати. Відразу після ХЦС та чотири дні потому спостерігається депресивноподібна поведінка шурів, яка супроводжується значним підвищенням вмісту L-аргініну, L-циитруліну та AФА з одночасним стимулюванням індуцчибельної ізоформи NO синтази в мітохондріях та циттозолі префронтального кортексу, стріатуму, гіпокампа і гіпоталамуса. При цььому відмічено пригнічення загальної активності конститутивних ізоформ NOS (cNOS) у цитозолі иих відділів мозку, тоді як для мітохондріальної сNOS статистично вірогідних змін не виявлено, за винятком зменшення ії активності у гіпоталамусі. Висновки. Порушення вмісту L-аргініну $i$ збалансованого синтезу NO в лімбічному мозку, очевидно, причетні до патогенезу депресії і тривоги.

Ключові слова: L-аргінін, мозок, хронічний стрес, депресивноподібна поведінка, мітохондрії, синтаза оксиду азоту.

Н. С. Назарян, Н. О. Мовсесян, Н. Х. Алчуджян, О. А. Мовсесян, А. Г. Геворкян, Р. Л. Айрапетян, К. А. Барсегян, Г. А. Геворкян

Различное продуцирование оксида азота в цитозольном и митохондриальном компартментах тканей головного мозга крыс при депрессивноподобном поведении, индуцированном хроническим стрессом

Резюме

Цель. Изучение субклеточного нитрергического ответа в участках мозга крыс при депрессивноподобном поведении, индуцированном хроническим стрессом. Методы. Использовали разработанную в нашей лаборатории животную (крыса) модель депрессии, индуцированную хроническим цииркадианным стрессом (ХЦС). L-аргинин, L-цчитруллин и активные формы азота (АФА) определяли спектрофотометрически. Результаты. Сразу после ХЦС и четыре дня спустя наблюдается депрессивноподобное поведение крыс, сопровождающееся значительным повыщением содержания L-аргинина, L-ичттруллина и АФА, с одновременным стимулированием индуцибельной изоформы NO синтазы в митохондриях и ичттозоле префронтального кортекса, стриатума, гиппокампа и гипоталамуса. При этом отмечено подавление общей актив- ности конститутивных изоформ NOS (cNOS) в цитозоле этих отделов мозга, тогда как для митохондриальной сNOS статистически достоверных изменений не выявлено, за исключением уменьшения ее активности в гипоталамусе. Выводы. Нарушения в содержании L-аргинина и сбалансированного синтеза NO в лимбическом мозге, по-видимому, причастны к патогенезу депрессии и тревоги.

Ключевые слова: L-аргинин, мозг, хронический стресс, депрессивноподобное поведение, митохондрии, синтаза оксида азота.

\section{REFERENCES}

1. Bredt D. S. Endogenous nitric oxide synthesis: biological functions and pathophysiology // Free Radic. Res.-1999.-31, N 6.P. 577-596.

2. Giulivi $C$. Mitochondria as generators and targets of nitric oxide // Novartis Found Symp.-2007.-287.-P. 92-100.

3. Rezin G. T., Amboni G., Zugno A. I., Quevedo J., Streck E. L. Mitochondrial dysfunction and psychiatric disorders // Neurochem. Res.-2009.-34, N 6.-P. 1021-1029.

4. Yanik M., Vural H., Tutkun H., Zoroglu S. S., Savas H. A., Herken H., Kocyigit A., Keles H., Akyol O. The role of the argininenitric oxide pathway in the pathogenesis of bipolar affective disorder // Eur. Arch. Psychiatry Clin. Neurosci.-2004.-254, N 1.-P. 43-47.

5. Alderton W. K., Cooper C. E., Knowles R. G. Nitric oxide synthases: structure, function and inhibition // Biochem. J.-2001.-357, Pt 3.-P. 593-615.

6. Nazaryan N. S., Movsesyan N. H., Alchujyan N. Kh., Movsesyan H. A., Guevorkian A. G., Hayrapetyan H. L., Kevorkian G. A. Depression-like condition and changes in the level of L-arginine and its metabolites in platelet and immunocompetent cells of blood in rat model of chronic circadian stress // Med. nauka Armeniyi NAN RA.-2011.-51, N 1.-P. 62-74.

7. Schmidt H. H. H. W., Kelm M. Determination of nitrite and nitrate by the Griess reaction // Methods in nitric oxide research / Eds M. Feelisch, J. S. Stamler.-Chichester: Wiley, 1996.P. 491-497.

8. Lowenstein C. J., Padalko E. iNOS (NOS2) at a glance // J. Cell Sci.-2004.-117, N Pt 14.-P. 2865-2867.

9. Brune $B$. The intimate relation between nitric oxide and superoxide in apoptosis and cell survival // Antioxid. Redox Signal.-2005.-7, N 34.-P. 497-507.

10. Bolanos J. P., Heales S. J. R. Persistent mitochondrial damage by nitric oxide and its derivatives: neuropathological implications // Front Neuroenergetics.- 2010.-2.-P. 1-9.

11. Wang D., An S. C., Zhang X. Prevention of chronic stress-induced depression-like behavior by inducible nitric oxide inhibitor // Neurosci. Lett..-2008.-433, N 1.-P. 59-64.

12. Hanania T., Johnson K. M. Regulation of neurotransmitter release by endogenous nitric oxide in striatal slices // Eur. J. Pharmacol.-1998.-359, N 2-3.-P. 111-117.

UDC 577.158:616.831-005 Received 10.07.11 